\title{
PERAN KOMUNIKASI PEKERJA SOSIAL DALAM PEGENDALIAN SOSIAL DAN PENGENDALIAN KESEHATAN MASYARAKAT
}

\author{
(Studi Kasus Kontribusi Kader TB Jaringan Kesejahteraan/Kesehatan \\ Masyarakat dalam Pengendalian Tuberkulosis di Jakarta Barat)
}

\author{
Rini Hardiyanti, Endang Tri Santi \\ Email: rhardiyanti@unis.ac.id, etrisanti@unis.ac.id \\ Program Studi Ilmu Komunikasi Universitas Islam Syekh Yusuf
}

\begin{abstract}
ABSTRAK
Pekerja sosial merupakan salah satu profesi yang kini sedang berjuang mengembangkan identitas dan eksistensinya, salah diantara mereka adalah Jaringan Kesejahteraan/Kesehatan Masyarakat (JKM). Melalui pendekatan epidemiologi, pekerja sosial ini secara khusus diperuntukkan untuk membantu pemerintah dalam mencegah, meminimalisir dan memecahkan masalah yang berkenaan dengan kesehatan masyarakat. Oleh karena itu, tujuan penelitian ini adalah untuk mengetahui bagaimana cara kader JKM dalam melakukan perannya sebagai salah satu profesi pekerja sosial dalam berkontribusi terhadap pengendalian TB di Jakarta Barat. Penelitian ini menggunakan desain deskriptif kualitatif, melalui wawancara mendalam pada kader dan kordinator lapangan yang memenuhi kriteria sebagai informan. Hasil penelitian ini menunjukkan bahwa peran kader JKM sangat dibutuhkan oleh pemerintah untuk berkontribusi dalam pengendalian tuberkulosis di Jakarta Barat, salah satunya untuk secara sukarela menjangkau para suspect TB hingga ke pelosok perkampungan yang mungkin belum dijangkau oleh pemerintah untuk diberikan sosialisasi dan konseling mengenai TB.
\end{abstract}

Kata Kunci : Pekerja sosial, Kesehatan masyarakat, Kader, Tuberkulosis

ABSTRACT

Social workers are one of the professions that are now struggling to develop their identity and existence, one of them is Jaringan Kesejahteraan/Kesehatan Masyarakat (JKM). Through an epidemiological approach, these social workers are specifically intended to assist the government in preventing, minimizing and solving problems relating to public health. Therefore, the purpose of this research is to find out how JKM cadres perform their role as one of the professions of social workers in contributing to TB control in West Jakarta. This study uses a qualitative descriptive design, through indepth interviews with cadres and field coordinators who have criteria as informants. The results of this study indicate that the role of JKM cadres is urgently needed by the government to contribute to tuberculosis control in West Jakarta, one of which is to voluntarily reach TB suspects in remote villages that may not be reached yet by the government to be given information and counseling about TB.

Keywords : Social worker, Public health, Cadre, Tuberculosis

12 | http://ejournal.unis.ac.id/index.php/DK/index 


\section{Pendahuluan}

Tuberkulosis (TB) merupakan salah satu penyakit menular kronis yang disebabkan oleh mycobacterium tuberculosis. Tidak saja penularan yang begitu cepat, TB juga merupakan penyakit yang dalam proses penyembuhannya memakan waktu yang cukup lama dengan jenis obat yang bermacam-macam. Di tahun 2009, terdapat 236.029 (BPS, 2009) kasus tuberkulosis yang ada di Indonesia, oleh karenanya Indonesia menempati peringkat kelima dalam kaus TB secara global (Global Tuberculosis Control: Epidemiology, Strategy and Financing. WHO Report 2011. Geneva, Switzerland: World Health Orgabization). Bahkan mungkin data terbaru, Indonesia telah naik peringkat pada posisi nomor 3 di dunia.

Jumlah kasus TB terus meningkat dengan angka kesembuhan yang tergolong rendah. Hal ini salah satunya dikarenakan terbatasnya deteksi kasus (pasien yang pasif), adanya keterlambatan diagnosis, minimnya penanganan kasus TB-MDR, terbatasnya pengetahuan tentang TB, dan terbatasnya dukungan dalam penanganan TB dari masyarakat dan program pemerintah. Selain itu, penderita TB sering terancam putus obat selama proses penyembuhan dengan berbagai alasan. Diantaranya, kurang sadarnya pasien harus minum obat sampai habis, pasien merasa sudah sehat sehingga berhenti minum obat, faktor ekonomi dalam menjangkau obat. Akibatnya, proses pengobatannya harus diulang dari awal dengan waktu lebih lama dan biaya yang jauh lebih mahal tentunya.

Berdasarkan KAP Survey tahun 2004, Signifikansi kenaikan kasus TB berdasarkan laporan dari Program TB Nasional, terdapat pengingkatan Case Detection Rate (CDR) dari $22 \%$ pada tahun 2000 menjadi 69\% pada tahun 2008. Data lain menunjukkan bahwa 20\% sampai $47 \%$ dari kasus TB diperkirakan masih belum terdeteksi dan masih banyak keterlambatan dalam diagnosis pasien. Situasi kemudian semakin sulit dikarenakan minimnya kesadaran pasien di Indonesia yang sadar akan resiko $\mathrm{TB}$, bagaimana cepatnya terjadi penularan, dan minimnya pengetahuan bagaimana cara pengobatan yang benar (dalam Materi Pelatihan Kader TB, CEPAT Program)

Hal yang tidak kalah pentingnya yakni adanya anggapan masyarakat bahwa TB merupakan penyakit keturunan, sehingga memalukan apabila memiliki anggota keluarga dengan TB. Stigma di masyarakat kian berkembang, sehingga anggapan bahwa TB merupakan penyakit orang miskin dan penyakit yang berhubungan dengan sihir, kemudian menjadikan TB sulit diobati karena tidak 
adanya kesadaran atau awareness dari masyarakat.

TB dapat menyerang siapa saja, terutama menyerang usia produktif atau orang yang masih aktif bekerja (15-60 tahun), tidak terkecuali anak-anak. TB juga dapat menyebabkan kematian apabila tidak diobati. 50\% dari pasien akan meninggal setelah 5 tahun apabila tidak mengikuti program penyembuhan melalui minum obat. Oleh karenanya, sejak tahun 1995, strategi penanggulangan TB yang direkomendasikan oleh WHO adalah dengan melaksanakan Directly Observed Treatment Shorcourse Therapy (DOTS). Pengendalian TB di Indonesia dengan menggunakan strategi DOTS merupakan pengobatan jangka pendek dengan pengawasan langsung, sehingga diharapkan mampu memberi angka kesembuhan yang tinggi dengan biaya yang paling efektif atau rendah.

Melalui data di atas, Jaringan Kesejahteraan/Kesehatan Masyarakat (JKM) merasa terpanggil untuk bergerak bersama dalam program penanggulangan dan pengendalian TB berbasis komunitas. Program TB CEPAT yang dilakukan oleh JKM dengan support dari USAID merupakan program kolaborasi JKM Medan dengan bagian Microbiologi UI, Microbiologi USU, fakultas kedokteran
Universitas Andalas, WESTAT serta melibatkan pakar TB.

Untuk melaksanakan program ini, tentu JKM tidak bekerja sendirian. JKM melakukan pelatihan terhadap masyarakat yang disebut kader JKM. Fungsinya adalah untuk mengajak dan memberdayakan masyarakat guna mencegah, mendeteksi dan mengobati TB. Adanya program pelatihan kader diharapkan mampu secara luas membantu program pemerintah dalam pengendalian kesehatan masyarakat khususnya TB. Program yang dilakukan oleh JKM difokuskan pada beberapa wilayah yang rentan terhadap $\mathrm{TB}$, terutama di daerah kumuh perkotaan, pulau-pulau terpencil, daerah pasca bencana, kelompok miskin, komunitas yang rentan dengan masalah gizi, dan komunitas yang memiliki kontak langsung dengan pasien TB. Salah satu yang menjadi fokus JKM adalah di Jakarta Barat yang beberapa kecamatannya terkenal dengan daerah padat penduduk dan kumuh.

Kader JKM dapat pula dikatakan sebagai pekerja sosial yang tidak hanya membantu kerja JKM tetapi juga membantu pemerintah dalam menurunkan angka prevalensi TB. Sebagai program pemberdayaan masyarakat, kader JKM juga diharapkan mampu menunjukkan identitas dan eksistensi diri secara mandiri tanpa paksaan dari pihak luar, sehingga 
kontribusi kader dapat dirasakan oleh seluruh lapisan masyarakat. Meskipun demikian, pemerintah pun diharapkan mampu menjadi wadah aspirasi bagi kader untuk menyampaikan dan mendorong lahirnya kebijakan yang berkenaan dengan kesehatan masyarakat.

Untuk itu, berdasarkan latar belakang di atas, penelitian ini bertujuan untuk mengetahui peran kader JKM sebagai salah satu profesi pekerjaan sosial dalam berkontribusi terhadap pengendalian TB yang ada di Jakarta Barat. Selain itu juga agar dapat mengetahui faktor apa saja yang dapat mempengaruhi kualifikasi sebagai seorang kader, sehingga memenuhi standarisasi dan sertifikasi kompetensi sebagai profesi pekerja sosial.

\section{Metodologi Penelitian}

Kajian mengenai Peran Pekerja Sosial dalam Pengendalian Kesehatan Masyarakat ini, mengunakan desain deskriptif kualitatif. Mohammad Nazir (Nazir, 1988;63) mengatakan bahwa tujuan dari penelitian deskriptif ini adalah untuk membuat deskripsi, gambaran atau lukisan secara sistematis, faktual, akurat mengenai fakta-fakta, sifat-sifat serta hubungan antar fenomena yang diselidiki.
Adapun penentu informan pada penelitian ini yaitu informan yang menjadi kader JKM dan koordinator lapangan. Pemilihan informan berdasarkan kriteria tertentu yang memiliki hubungan dengan maksud penelitian yang telah diketahui sebelumnya (Sugiono, 2007;53-54).

$$
\text { Pengumpulan data dilakukan }
$$
dengan cara pengumpulan dari sumber data primer yakni hasil wawancara kepada primer, dan sumber data sekunder sebagai data pendukung dari literatur atau dokumen serta data yang diambil dari suatu organisasi atau institusi. Data sekunder dari penelitian ini diambil dari JKM Indonesia khususnya wilayah distrik Jakarta Barat.

Sebetulnya pada proses pengumpulan dan analisa data merupakan proses yang bersamaan dalam penelitian kualitatif menurut Marshall \& Rossman (dalam Cresswell, 2003:160). Analisa data merupakan proses mencari dan menyusun secara sistematis data yang diperoleh dari hasil wawancara, catatan lapangan dan dokumentasi dengan cara mengorganisasikan data ke kategor, menjabarkan ke unit-unit, melakukan sintesa, menyusun ke dalam pola, memilih mana yang penting dan yang akan dipelajari dan membuat kesimpulan sehingga mudah dipahami oleh diri sendiri maupun orang lain. 
Analisa data dilakukan sejak sebelum memasuki lapangan, selama di lapangan dan selesai di lapangan. Untuk itu teknin analisa data yang digunakan dalam penelitian ini adalah menggunakan model Miles dan Hubermen (dalam Sugiono, 2010:91) yakni analisis yang dilakukan secara terus menerus.

Terakhir dalam metodologi penelitian ini menggunakan uji keshahihan atau keabsahan data. Sebagai uji keshahihan dan keabsahan data dalam penelitian ini menggunakan trianggulasi. Trianggulasi di sini digunakan sebagai pendekatan untuk memperdalam pengetahuan dengan pendekatan kualitatif. Oleh sebab itu, dalam pengujian keabsahan data, penelitian ini menggunakan triangulasi data atau triangulasi sumber, di mana data akan dikumpulkan melalui sumber yang beragam, misalnya wawancara dan analisa dokumen sehingga akan lebih mudah menguji kebenarannya.

\section{Pembahasan dan Hasil Penelitian}

Kader TB adalah anggota masyarakat yang bekerja secara sukarela dalam membantu pengendalian TB sesuai dengan kemampuannya. Adapun peran kader $\mathrm{Tb}$ dalam pengendalian TB adalah mengatasi masalah TB di wilayahnya. Di wilayah Jakarta Barat sendiri peran kader yakni diantaranya :

a. Memberikan penyuluhan tentang TB dan pengendaliannya kepada masyarakat

b. Membantu menemukan pasien TB yang dicurigai sakit TB dan pasien TB di wilayahnya

c. Membantu puskesmas atau sarana kesehatan lainnya dalam membimbing dan memberikan motivasi kepada Pengawas Menelan Obat (PMO) untuk selalu melakukan pengawasan menelan obat.

d. Menjadi koordinator PMO

e. Jika pasien tidak memiliki PMO, maka seorang kader dapat menjadi PMO.

Selain itu, peran yang dilakukan kader JKM seperti yang sudah disebutkan di atas, terdapat pula tugas kader yang tidak kalah penting, diantaranya :

a. Menginformasikan bahwa pemeriksaan dan tatalaksana TB dapat dilakukan di Sarana Pelayanan Kesehatan DOTS (Puskesmas, klinik swasta dan rumah sakit)

b. Menyarankan orang tersebut untuk memeriksakan diri ke Sarana Pelayanan Kesehatan DOTS (Puskesmas, klinik swasta, rumah sakit) yang terdekat 
c. Melaporkan orang yang diduga $\mathrm{Tb}$ di wilahnya kepada petugas kesehatan.

Dari beberapa peran dan tugas kader JKM yang telah dijelaskan di atas, rasanya tidak berlebihan jika diasumsikan bahwa kader melalui perannya yang ikut mendorong program pemerintah dalam pengendalian $\mathrm{TB}$, merupakan salah satu profesi pekerja sosial yang harus diakui identitas dan eksistensinya. Tugas kader yang ikut membantu dalam mencegah, meminimalisir dan memecahkan masalah kesehatan, merupakan salah satu tugas pekerja sosial yang dalam pelaksanaannya sungguh tidak mudah.

Tujuan adanya kader JKM yang memiliki peran dan tugas pokok tersebut di atas adalah tentu membantu pemerintah dalam mensosialisasikan bagaimana agar penanggulangan TB atau angka penurunan TB di Indonesia segera tercapai. Kader merupakan salah satu ujung tombak masyarakat yang ikut andil dalam pengendalian kesehatan masyarakat, sehingga perannya harus dihargai dan diberi penghargaan serta wadah dalam pengembangan eksistensi diri.

Untuk itu, dalam melaksanakan perannya sebagai salah satu profesi pekerja sosial dalam pengendalian TB yang ada di daerah Jakarta Barat, terdapat beberapa cara yang menjadi perhatian kader, diantaranya :

\section{a. Memperhatikan Proses Komunikasi} Kader terhadap pasien dalam Pengendalian Tuberkulosis di wilayah Jakarta Barat.

1) Pengertian Komunikasi

Secara terminologi komunikasi berasal dari bahasa Latin yakni communico yang artinya membagi, dan communis yang berarti membangun kebersamaan antara dua orang atau lebih (Cangara, 2009:13). Dalam Effendy (2004:9) dikatakan bahwa kegiatan komunikasi tidak hanya bersifat informatif yang hanya mampu memberikan pengetahuan dan pengertian kepada orang lain, tetapi juga bersifat persuasif, yakni agar orang lain bersedia menerima suatu paham atau keyakinan untuk suatu perbuatan dan kegiatan lainnya.

Dari pengertian komunikasi, kader diharapkan mampu membangun kebersamaan dengan pasien, sehingga informasi atau pengetahuan yang disampaikan oleh kader dapat diterima dengan baik oleh pasien atau pun keluarga pasien.

2) Kegunaan dan tujuan komunikasi

Adapun kegunaan komunikasi antara lain :

- Menyampaikan informasi

- Mendidik 
- Menghibur

- Mempengaruhi

Sedangkan tujuan komunikasi, antara lain :

- Adanya perubahan sikap

- Adanya perubahan pendapat

- Adanya perubahan perilaku

- Adanya perubahan sosial

Dari kegunaan dan tujuan komunikasi di atas terlihat bahwa peran kader dalam melakukan komunikasi kepada pasien sangatlah penting. Bukan hanya bertujuan untuk menyampaikan informasi saja, tetapi lebih pada persoalan perubahan baik berupa perubahan sikap, pendapat, perilaku maupun perubahan sosial, dalam hal ini masyarakat harus aware dengan adanya lingkungan sekitar sehingga dengan mudah dapat mencegah dan menanggulangi TB di Indonesia.

\section{3) Unsur-unsur komunikasi}

Dalam proses komunikasi ada 5 unsur dasar yaitu :

a. Komunikator

Komunikator adalah orang yang menyampaikan pesan kepada komunikan. Dalam konteks penanggulangan TB, ungkapan tersebut sangat bermakna mengingat komunikasi yang dilakukan oleh kader tidak akan cukup satu kali, kita memerlukan kesediaan waktu dari pihak penerima pesan dalam hal ini adalah pasien. Oleh karena itu kader perlu menjalin hubungan yang baik dengan pasien.

b. Pesan

Pesan adalah informasi yang ingin disampaikan oleh pengirim kepada penerima. Pesan yang disampaikan dapat berupa pesan verbal, yakni semua jenis komunikasi lisan yang menggunakan kata-kata, dan dapat juga berupa pesan non verbal, seperti bahasa tubuh (ekspresi wajah, sikap tubuh, nada suara, gerakan tangan, cara berpakaian dan sebagainya), musik, tarian dan bahasa isyarat.

c. Saluran

Saluran merupakan media atau sarana yang digunakan supaya pesan dapat disampaikan oleh sumber kepada si penerima.saluran seringkali disebut dengan metode komunikasi. Saluran komunikasi bisa saja sederhana, misalnya menggunakan kata-kata atau suara, tetapi juga prosesnya belum tentu dapat sederhana. Misalnya kita dapat menggunakan radio untuk kampanye tingkat kota, bisa menggunakan leaflet, dan lainnya. 
Saluran yang digunakan untuk menjangkau masyarakat, antara lain memggunakan media seperti surat kabar lokal, stasiun radio, majalah lokal, TV lokal, buletin, poster, pemutaran film, seperti pameran kesehatan atau khusus media tradisional dan lain-lain.

Dalam penyuluhan TB dapat dilakukan dengan mengadakan pameran tentang TB, lomba di bidang kesehatan dan lain-lain.

d. Penerima

Penerima atau biasa disebut komunikan adalah orang-orang yang menerima pesan dari komunikator. Penerimaan pesan dalam konteks penanggulangan TB dapat berupa perorangan, kelompok, kelembagaan dan masyarakat.

e. Dampak

Dampak adalah akibat yang dihasilkan oleh adanya proses komunikasi, setelah adanya penafsiran pesan oleh penerima. Dampak yang diharapkan dapat berupa terjadinya perubahan positif dalam hal pengetahuan, sikap dan perilaku terhadap TB dan penanggulangannya.

Secara praktis, tentu kader mengalami hambatan dalam komunikasi yang dilakukan dengan pasien, diantaranya :

a. Faktor pengetahuan, sikap, dan keterampilan serta kondisi fisik atau psikis kader yang kurang prima, sehingga mempengaruhui peran kader dalam melakukan pengendalian TB.

b. Kurangnya pengetahuan dan pengalaman komunikan yang berkaitan dengan TB, kondisi fisik dan psikis pasien yang kurang prima, sehingga kurang siap ketika berkomunikasi dengan kader.

c. Faktor pesan, yakni penggunaan istilah atau bahasa yang sulit dimengerti, pesan terlalu panjang, pesan yang terkesan menakut-nakuti, bukan motivasi atau persuasi.

d. Pentingnya Pengetahuan kader tentang peran komunikasi dalam perubahan perilaku

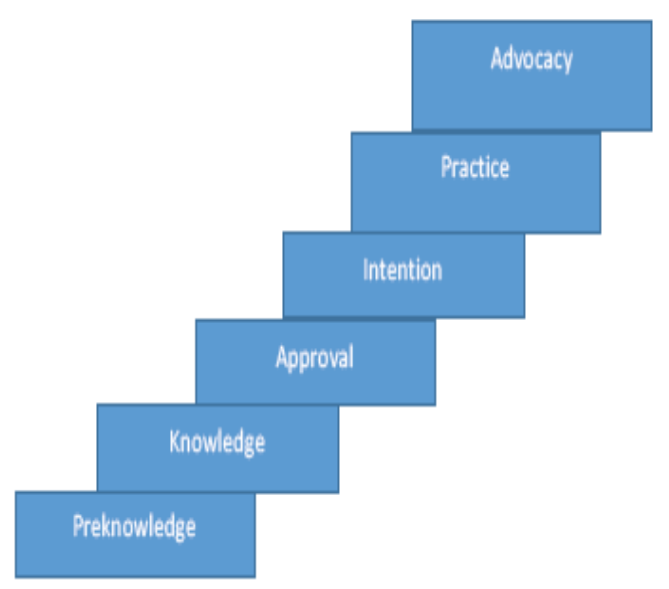

Gambar 1. Process of Behavior Change (Proses Perubahan Perilaku) 
Gambaran proses perubahan perilaku tersebut menunjukkan bahwa proses perubahan meliputi tahapan sebagai berikut :

1. Preknowledge : tidak tahu atau tidak memiliki pengetahuan

2. Knowledge : tahu atau memiliki pengetahuan

3. Approval : menerima pengetahuan atau menerima pesan yang disampaikan

4. Intention : menaruh perhatian terhadap pesan yang disampaikan

5. Practice : mempraktikkan pesan yang telah diterima

6. Advocacy : mengajak atau mempengaruhi orang lain tentang pesan yang diterimanya.

Dari skema yang dijelaskan di atas, peran kader sangat dibutuhkan dalam proses perubahan perilaku. Yakni, kader dengan segala kemampuannya dalam berkomunikasi harus mampu melakukan sosialisasi atau penyuluhan kesehatan terhadap masyarakat yang awalnya tidak tahu sama sekali kemudian menjadi paham, setelah paham khalayak mau menerima pesan yang disampaikan sehingga terjadi awareness di masyarakat soal TB. Kemudian masyarakat mempraktikkan pesan yang disampaikan oleh kader, sampai pada akhirnya masuk ke tahap advokasi dalam rangka mengajak dan mempengaruhi masyarakat secara luas.

$$
\text { Setelah kader melakukan }
$$

komunikasi yang dapat mempengaruhi perubahan perilaku khalayak, maka kemudian sosialisasi atau penyuluhan yang dilakukan kader dalam penanggulangan TB pun ikut mengalami proses perubahan perilaku dalam penanggulangan $\mathrm{TB}$, adalah sebagai berikut :

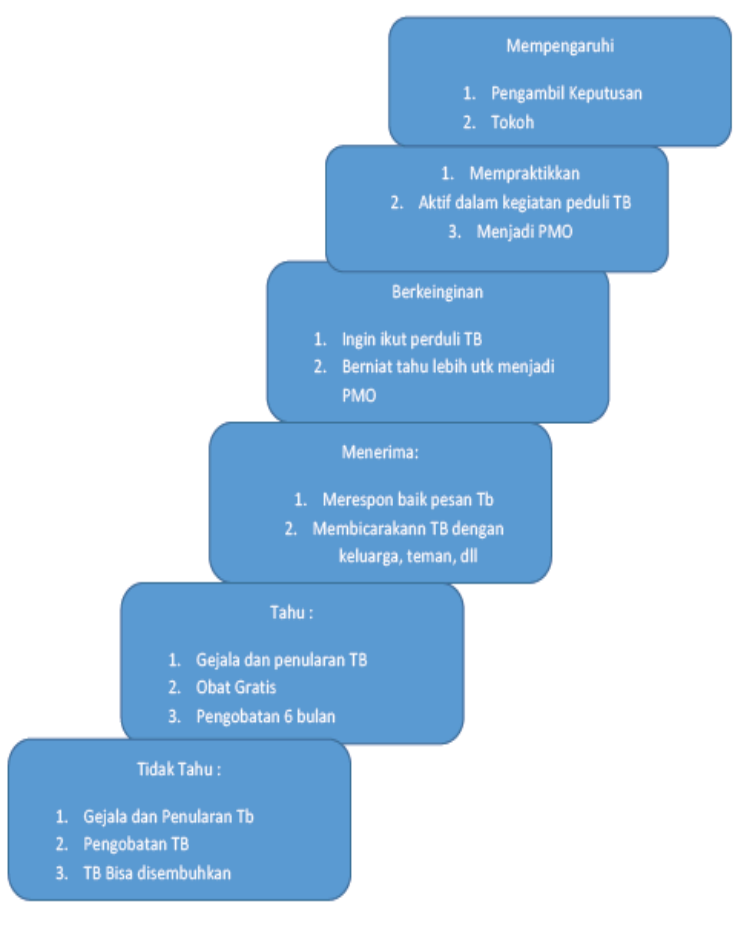

Gambar 2. Proses Perubahan Perilaku dalam Penanggulangan TB

Berdasarkan skema tersebut di atas, tahap awal kader melakukan perubahan perilaku dalam penanggulangan TB adalah dengan cara memberikan penyuluhan dan sosialisasi terhadap pentingnya kepedulian akan TB. Adapun penjelasan skema di atas adalah : 
a. Tahap awal proses perubahan dimulai dari membuat masyarakat yang tidak tahu tentang TB, menjadi tahu.

b. Tahap kedua adalah tahap penerimaan masyarakat terhadap pesan atau pengetahuan yang diperoleh dari kader

c. Tahap ketiga adalah tahap berkeinginan. Adanya kesadaran bahwa TB perlu ditanggulangi oleh semua pihak, bukan hanya oleh kader saja. Hal ini ditandai dengan adanya niat untuk tahu lebih banyak tentang TB yang ditunjukkan antara lain banyak bertanya tentang TB kepada kader atau petugas TB.

d. Mempraktikkan. Maksudnya adalah mewujudkan keinginan dan niat menjadi kenyataan, misalnya masyarakat mulai berkonsultasi kepada kader atau petugas TB.

e. Mempengaruhi. Merupakan tahap proses perubahan perilaku yang paling tinggi, karena pada tahap ini peran kader tidak hanya sebatas sosialisasi saja akan tetapi juga mampu mempengaruhi masyarakat dalam berperan serta untuk menanggulangi TB.

\section{Kesimpulan \& Saran}

\section{Kesimpulan}

Berdasarkan pembahasan dan hasil penelitian di atas dapat diketahui bagaimana cara kader JKM dalam melakukan perannya sebagai salah satu profesi pekerja sosial dalam berkontribusi terhadap pengendalian TB di Jakarta Barat, yakni dengan cara melakukan komunikasi yang baik dan efektif terhadap masyarakat khususnya terhadap pasien TB. Komunikasi yang dilakukan oleh kader tujuannya adalah untuk mempengaruhi pasien dan keluarga pasien agar lebih aware terhadap tuberkulosis. Selain itu agar kader dapat memenuhi kualifikasi dan standarisasi sebagai pekerja sosial, harus memiliki pengetahuan dan kemampuan komunikasi yang baik agar dapat mempersuasi masyarakat dalam mewujudkan kesehatan masyarakat khususnya TB. Setelah kedua hal tersebut mampu terwujud, baru kemudian dapat menyampaikan aspiarasi terhadap pemerintah bahwa harus adanya perhatian khusus terhadap pekerja sosial sehingga keberadaannya dapat diakui dan diberi penghormatan. 


\section{Saran}

Adanya kendala dalam hal transportasi kader, diharapkan bisa mendapatkan dukungan dari pemerintah secara penuh agar para kader dalam menjalankan tugasnya, baik dalam melakukan komunikasi perihal TB maupun mempersuasi masyarakat dan mewujudkan kesehatan masyarakat bisa tercapai.

\section{Daftar Pustaka}

Buku Internal JKM. 2012. Materi Pelatihan Kader TB, CEPAT Program. Medan: Yayasan JKM

Cangara, Hafid. 2009. Pengantar Ilmu Komunikasi. Jakarta:PT. Raja Grafindo Persada

Creswell, W. John. 2002. Research Design. Jakarta:KIK Press

Efendy, Omong Uchjana. 2004. Dinamika Komunikasi. Bandung: PT. Remaja Rosda Karya

Nazir, Moh. 1998. Metode Penelitian. Jakarta:Galia Indonesia

Sugiyono. 2011. Metode Penelitian Kuantitatif-Kualitatif dan $R \& D$. Bandung: Alfabet 